\title{
МОДЕЛЮВАННЯ РОБОТИ ГІДРОАКУМУЛЮВАЛЬНОЇ ЕЛЕКТРОСТАНЦІЇ В ГЕНЕРАТОРНОМУРЕЖИМІ ПАРАЛЕЛЬНО 3 ВІТРОЕЛЕКТРОСТАНЦІЕЮ НА АВТОНОМНУ МЕРЕЖУ
}

\author{
А.П. Вербовий, канд. техн. наук
}

Інститут відновлюваної енергетики НАН України, 02094, вул.ГнатаХоткевича,20А, м. Київ, Україна.

У міру збільшення встановлених потужностей відновлюваних джерел енергї на основі сонячних та вітроелектростанцій збільшується необхідність у резервних джерелах потужності. Серед недоліків відновлюваних джерел енергії, які обмежують їх широке застосування, -невисока шільність енергетичних потоків і їх мінливість у часі. Особливо цей фактор впливає на виробництво електроенергії вітро- $і$ фотоелектростаниіями: графік виробництва енергії має імовірнісний характер. Джерелом маневрової потужності може бути гідроакумулювальна електростанція. Гідроакумулювальні електростаниії за досить тривалий час зарекомендували себе як відносно прості й надійні станції, щзо володіють максимальними маневреними можливостями - швидким набором та скиданням навантаження, великим діапазоном регулювання.

Стаття присвячена розробленню імітаційної моделі гідроакумулювальної електростанції в генераторному режимі роботи паралельно з вітроелектростанцією на автономну мережу. За основу взята відома модель-вітротурбіназ асинхронним генератором у складі вітродизельної системи в ізольованій електричній мережі, яка була доповнена блоками гідравлічноі турбіни з регулятором та синхронним генератором. Модель реалізована у сучасному математичному пакеті МАTLAB. $3 a$ допомогою створеної моделі були проведені теоретичні дослідження роботи вітротурбіни з асинхронним генератором при застосуванні стохастичної складової швидкості вітру. При иььому було проаналізовано вплив стохастичної складової швидкості вітру на вихідні параметри асинхронного генератора, як-от швидкість, частота, напруга, струм. Також були проведені дослідження гідравлічної турбіни та синхронного генератора в динамічних $і$ квазістатичних режимах роботи. Розроблена імітаційна модель роботи гідроакумулювальної електростанції паралельно з вітроелектростанцією на автономну мережу дозволяє досліджувати параметри електричної енергї як в стаціонарних, перехідних режимах роботи, так $і$ в аварійних. В роботі доведено, щуо стохастична складова швидкості вітру суттєво впливає на частоту обертання й частоту мережі, щзо зумовлює зміну вихідних електричних параметрів, які впливають на всю електромеханічну систему. Бібл. 21 , рис. 7.

Ключові слова: стохастична, гідроакумулювальна електростанція, ивидкість, частота, напруга, струм.

\section{MODELING OF PUMPED HYDRO STORAGE STATION IN GENERATOR MODE PARALLEL WITH WIND POWER PLANT ON AUTONOMOUS ENERGY SYSTEM}

\section{A. Verbovij}

Institute of Renewable Energy, NAS of Ukraine, 02094, St. Hnata Khotkevycha, 20A, Kyiv, Ukraine.

As the installed capacity of renewable energy sources based on solar and wind power plants increases, the need for backup power sources increases. The disadvantages of renewable energy sources, which limit their widespread use, are the low density of energy flows and their variability over time. This factor especially affects the production of electricity by wind and photo power plants: the schedule of energy production is probabilistic. The source of shunting power can be a storage power plant. Hydro accumulation power plants have long established themselves as relatively simple and reliable stations with maximum maneuverability - fast dialing and load relief, a wide range of regulation.

A simulation model of a hydro-accumulating power plant in the generator mode of operation in parallel with a wind power plant on an autonomous network has been developed. The known model of a wind turbine with an asynchronous generator as a part of a wind diesel system in the isolated electric network which was supplemented was supplemented by blocks of the hydraulic turbine with the regulator and the synchronous generator is taken. The model is implemented in a modern mathematical package MATLAB. With the help of the created model theoretical researches of work of the wind turbine with the asynchronous generator at application of a stochastic component of wind speed were carried out. The influence of the stochastic component of wind speed on the output parameters of the asynchronous generator, such as speed, frequency, voltage, current, was analyzed. Studies of a hydraulic turbine and a synchronous generator in dynamic and quasi-static modes of operation were also carried out. The developed simulation model of PSP 
operation in parallel with the wind farm on the autonomous network allows to study the parameters of electric energy in stationary, transient, and emergency modes. It is proved that the stochastic component of wind speed significantly affects the speed and frequency of the network, which causes a change in the output electrical parameters that affect the entire electromechanical system. Ref.21, fig. 7. Keywords: stochastic, pumped storage hydro station, speed, frequency, voltage, current.

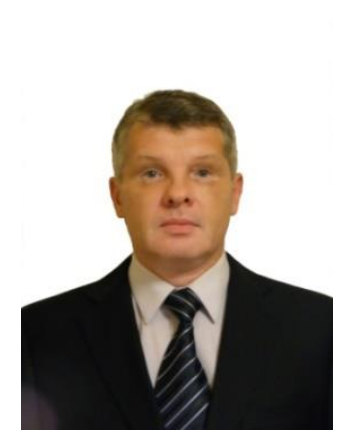

А.П. Вербовий

A. Verbovij
Відомості про автора: старший науковий співробітник відділу гідроенергетики Інституту відновлюваної енергетики НАНУ Освіта: Національний технічний університет України «Київський політехнічний інститут імені Ігоря Сікорського». Спеціальність «Електропривод та автоматизація промислових установок»

Наукова сфера: відновлювана енергетика, гідроенергетика, генератор.

Публікації: 129

ORCID: 0000-0003-2838-6032

Контакти: тел./факс: +38(044)206-28-09

e-mail: hydro@ive.org.ua
Author Information: Senior Researchof Hydropower Engineering Department, Institute of Renewable Energy NAS of Ukraine Education: Natiwnal Technical University of Ukraine «Igor Sikorsky Kyiv Polytechnic Institute».Specialty: «Electric drive and automation of industrial plants»

Reasearch area: renewable energy, hydropower, generator.

Publications: 129

ORCID: 0000-0003-2838-6032

Contacts: +38(044)206-28-09

e-mail: hydro@ive.org.ua

Перелік використаних позначень та скорочень:

ВДЕ - відновлювані джерела енергії;

ВЕС - вітроелектростанція;

ФЕС - фотоелектростанція;

ГАЕС -гідроакумулювальна електростанція;

Вступ. Скорочення запасів органічного палива та загострення екологічних проблем привертають дедалі більший інтерес у світі до використання природних відновлюваних джерел енергії (ВДЕ). Перевагою ВДЕ насамперед є сам факт їхньої невичерпності. У перспективі виробництво енергії, що використовує органічне паливо (вугілля, природний газ, мазут, дизельне паливо), може зіткнутися 3 низкою складних економічних, транспортних i екологічних проблем. Відсутність на внутрішньому ринку країни енергетичної альтернативи, може призвести до негативних наслідків через поступове виснаження традиційних енергоносіїв. У зв'язку з цим є необхідність у використанні альтернативних, ефективних та економічно вигідних способів енергозабезпечення споживачів $[1,2]$.

Пропорційно зі збільшенням встановленої потужності сонячних і вітроелектростанцій (CEC,BEC) [3-5], потреби у резервних маневрених джерелах потужності збільшуватимуться. Одним із варіантів
ЕМС - електромеханічна система;

$\mathrm{AГ}$ - асинхронний генератор;

СГ- синхронний генератор. вирішення такої проблеми може бути застосування малої гідроакумулювальної електростанції (ГАЕС) [6-8].

Мета роботи полягає у впровадженні в практику досконаліших методів моделювання, розрахунку i проєктування, заснованих на максимально повному врахуванні реальних параметрів всієї електромеханічної системи (EMC), що дозволить отримати розрахункові, технічні характеристики й параметри створюваного об’єкта при необхідних навантаженнях i передбачуваних умовах експлуатації [9-11].

Імітаційна модель. Дослідження моделі роботи ГАЕС в генераторному режимі паралельно ВEC на автономну мережу доцільно реалізовувати в сучасних математичних програмних пакетах. При цьому значно скорочуються витрати на проведення безпосереднього чисельного експерименту, оскільки параметри моделі уточнюються ще в ході комп'ютерного моделювання. У більшості випадків сучасні засоби моделювання дозволяють забезпечити 
високий рівень адекватності моделі. Одним 3 таких засобів, який завдяки своїм функціональним i інтерфейсним можливостям найбільш широко використовується при проведенні різного роду розрахунків та досліджень $\epsilon$ математичний пакет MATLAB $[12,13]$. Імітаційне моделювання - це метод дослідження, при якому система, що вивчається, замінюється моделлю, 3 достатньою точністю описує реальну систему, 3 якою проводяться експерименти 3 метою отримання інформації про цю систему.

За основу взята імітаційна модель, яка представлена в [14], де досліджується вітротурбіна з асинхронним генератором у складі вітродизельної системи в ізольованій електричній мережі [15,16]. До складу моделі входять вітротурбіна 3 асинхронним генератором, повна потужність якого становить 275 кВт, а також вітродизельна система 3 синхронною машиною потужністю 300 кВт. При низькій швидкості вітру асинхронний генератор (АГ) i дизельний синхронний генератор (СГ) працюють паралельно для подачі необхідної напруги на навантаження. Коли енергія вітру перевищує потужність навантаження, дизельний генератор вимикається, i синхронна машина працює як синхронний компенсатор. В даній моделі робота дизельгенератора не моделюється. Навантаження складається 3 основного, потужністю 50 кВт, додаткового - 25 кВт і вторинного. Вторинний блок навантаження використовується для регулювання частоти всієї системи шляхом поглинання надлишкової енергії вітру, коли вона перевищує попит споживачів. Величина навантаження може змінюватися від 0 до 446,25 кВт 3 кроком в 1,75 кВт як в одну, так і в іншу сторону. Для вирівнювання частоти мережі застосований регулятор, який використовує стандартну систему автоматичного підстроювання. Виміряна частота порівнюється 3 заданою для отримання похибки відхилення за частотою $[17,18]$. Ця похибка інтегрується для отримання фазової похибки, яка потім використовується пропорційно-інтегралльнодиференціальним (PID) контролером для отримання вихідного сигналу, який являє собою необхідну кількісну величину потужності вторинного навантаження.

Модель, розглянута в роботі [14], була доповнена блоками гідравлічної турбіни (ГТ) 3 регулятором та синхронним генератором. Система регулювання включає пропорційнодиференціальний (ПІД) регулятор та керуючий сервомотор. Загальна схема моделі ГТ показана на рис. 1.

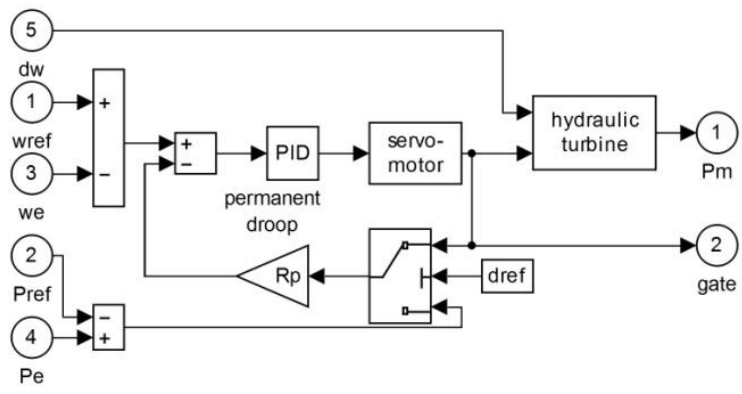

Рис. 1.Схема моделі гідравлічної турбіни

Fig. 1. Scheme of the hydraulic turbine model

На перші два входи блоку подаються необхідні значення кутової швидкості (wref) та потужності (Pref). На третій та четвертий входи блоку надходять фактичні значення швидкості (we) та активної потужності (Ре). На п'ятий вхід подається відхилення швидкості ротора синхронного генератора (dw). Вихідними сигналами $\epsilon$ механічна потужність, яка повинна подаватися на відповідний вхід блоку синхронної машини $(\mathrm{Pm})$, та величина відкриття затвору гідротурбіни (gate). Входи 2 i 4 можуть залишатися непідключеними, якщо як зворотний зв'язок буде використовуватися сигнал про положення затвора, а не відхилення швидкості.

Загальна схема моделі представлена на рис. 2. 


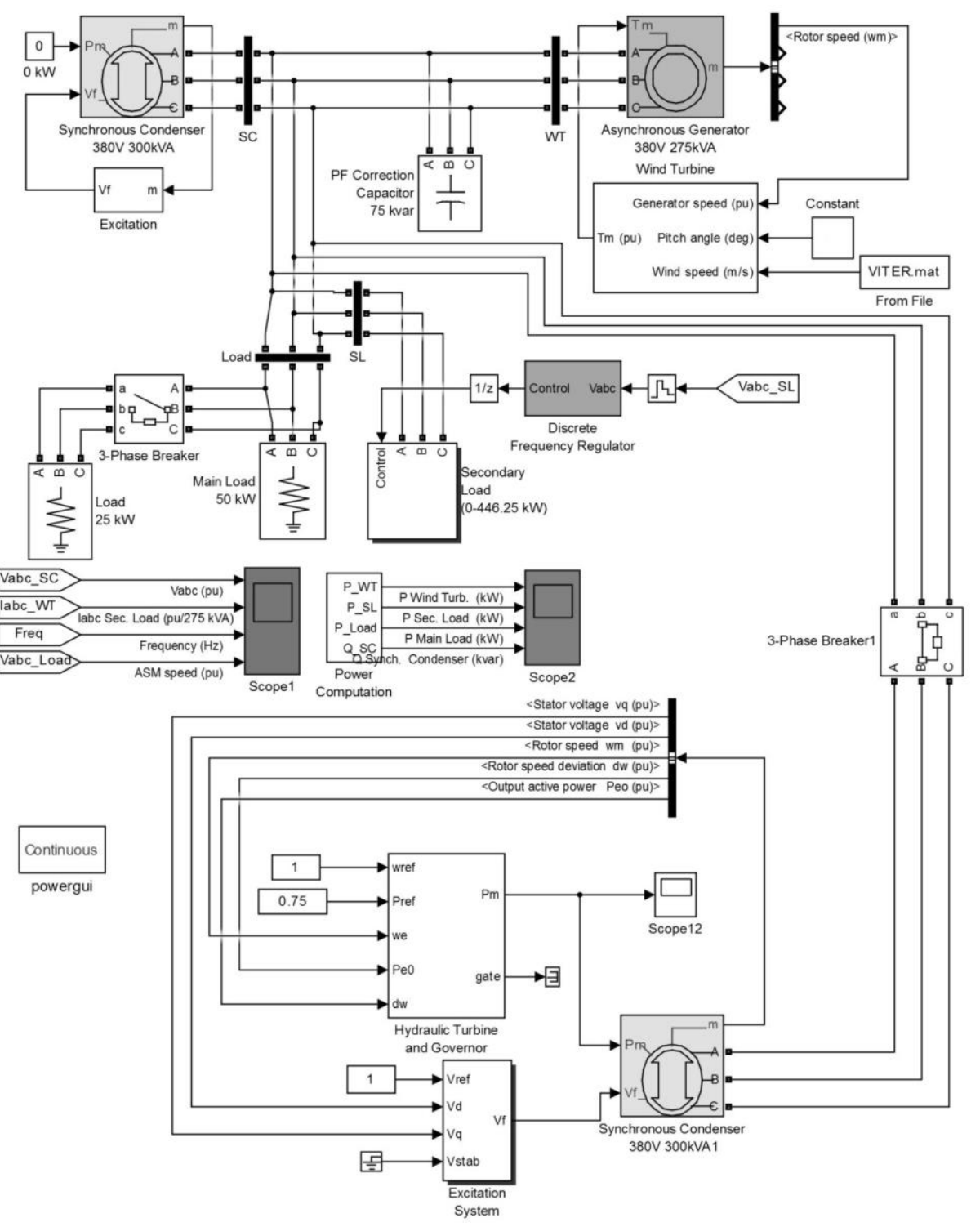

Рис. 2. Схема роботи моделі ГАЕС в генераторному режимі паралельно з ВЕС

Fig. 2. The scheme of operation of the PSPP model in the generator mode in parallel with the wind farm

Дослідження і робота моделі проводились за таким алгоритмом при допущенні, що кут повороту лопаті приймаємо постійним і рівним $\beta=1$ : в початковий момент сигнал стохастичної складової швидкості вітру надходить на блок вітротурбіни [19], 3 якої сигнал обертового моменту подається на АГ. Вихідна напруга генератора надходить на основне навантаження; на 10-й секунді до мережі підключається додаткове навантаження $[20,21]$. На 15 -й секунді включається гідравлічна турбіна, яка в свою чергу обертає СГ, 3 якого напруга надходить в автономну мережу. 3 цієї миті СГ працює паралельно з АГ.

Результати моделювання. На рис.3 зображений графік фазної напруги автономної мережі, щомає вигляд синусоїди, дійсне значення якого становить 220 В. Упочатковий момент часу моделювання відбуваються коливання напруги, внаслідок виникнення перехідного режиму. При підключені додаткового навантаження спостерігається незначне падіння напруги, але при приєднанні до мережі СГ дійсне значення напруги повертається до номінального значення, $\mathrm{i}$ надалі не змінюється. 


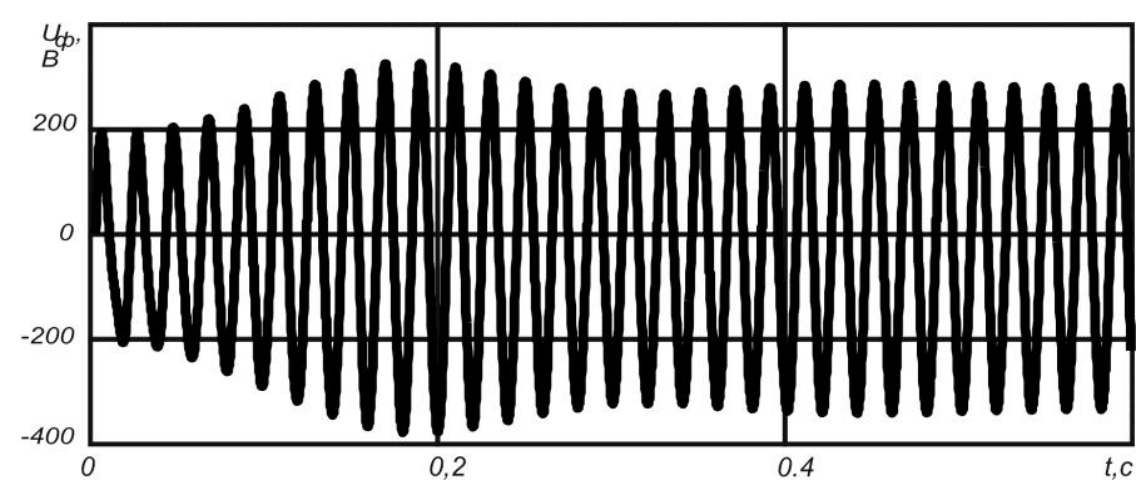

Рис. 3. Фазна напруга автономної мережі

Fig. 3. Phase voltage of the autonomous network

Зміна струму АГ (рис. 4) має мінливий швидкості вітру. В початковий момент і в момент характер, який залежить від навантаження i підключення додаткового навантаження струм АГ швидкості генератора.Так самойого швидкість збільшується і потім протікає в квазістатичному залежить від швидкості вітротурбіни, яка в свою режимі через непостійність швидкості вітру.

чергу залежить від стохастичної складової

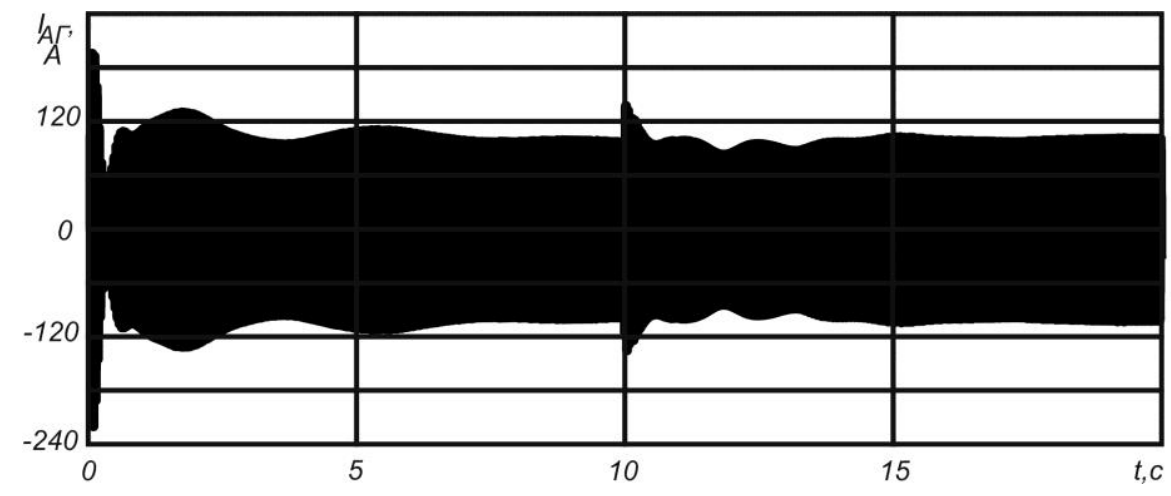

Рис. 4. Струм асинхронного генератора вітроелектростанції

Fig. 4. Current of induction generator of wind power plant

Струм СГ (рис. 5) в початковий момент пуску вдвічі більший номінального і має нестійкий характер, що відбувається через коливання швидкості на валу гідравлічної турбіни (рис. 6, графік 2). Але внаслідок роботи PID регулятора, який подає сигнал на сервомотор,

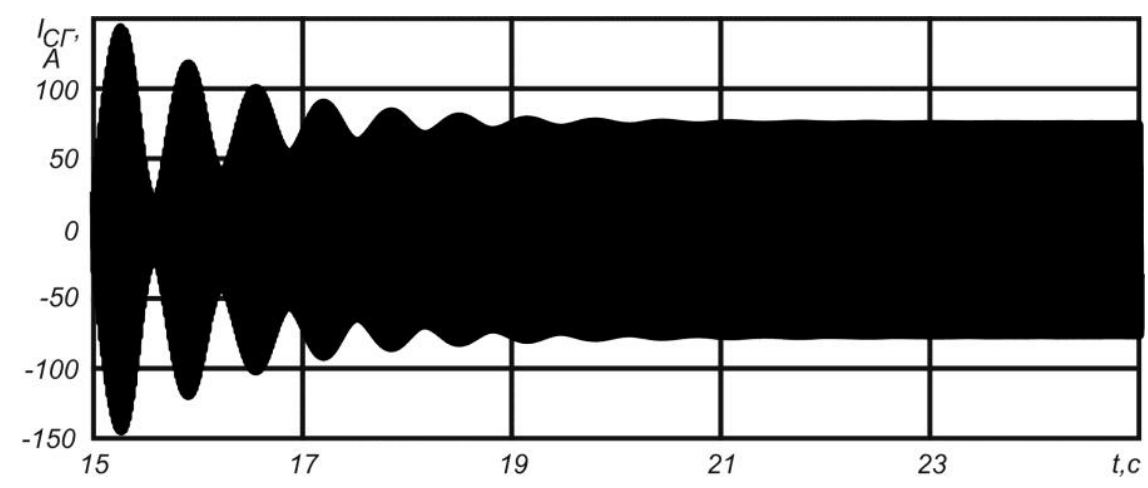

Рис. 5. Струм синхронного генератора гідроакумулювальної електростанції

Fig. 5. Current of the synchronous generator of the pumped storage power plant 


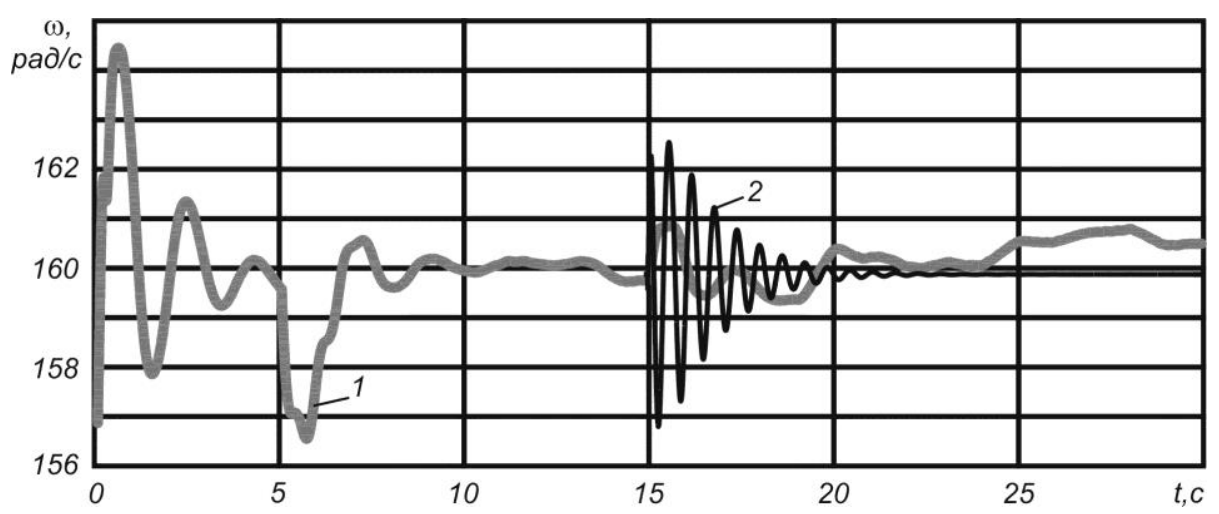

Рис. 6. Швидкість асинхронного (1) і синхронного (2) генераторів

Fig. 6. Speed of induction (1) and synchronous (2) generators

На графіках частоти, зображених на рис. 7 спостерігаються коливання, які найбільші в моменти комутації;іх значення по амплітуді досягають 1 Гц. Для порівняння були проведені дослідження відхилення частоти від номінального значення для двох значень швидкості вітру, для стохастичної складової (рис. 7, графік 1) i постійної, 8 м/с (рис. 7, графік 2).На графіках можна побачити, що в моменти комутації вони практично не відрізняються. Але в квазістатичному режимі (відрізок кривих від 16 до 30 c) характер їх різний. При постійній швидкості вітру, частота мережі практично не відхиляється від номінальної, 50 Гц, а при застосуванні стохастичної складової вона відхиляться від номінального значення на 0,2%. При поривах швидкості вітру вона буде відхилятися ще більше, що потрібно враховувати.

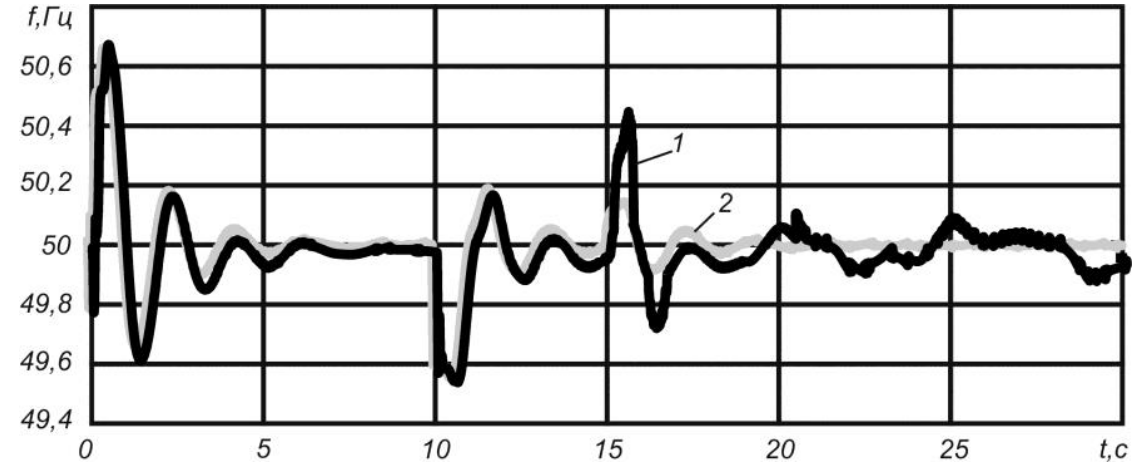

Рис. 7. Графіки частоти напруги автономної мережі при стохастичній (1) та постійній (2) швидкостях вітру

Fig. 7. Graphs of the frequency of the voltage of the autonomous network at stochastic (1) and constant (2) wind speeds

Висновки. Розроблена імітаційна модель роботи ГАЕС паралельно з ВЕС на автономну мережу дозволяє досліджувати параметри електричної енергії як в стаціонарних, перехіднихрежимах роботи, так і в аварійних. В роботі доведено, що стохастична складова швидкості вітру суттєво впливає на частоту обертання та механічний момент генератора, що зумовлює зміну вихідних електричних параметрів, які впливають на всю ЕМС. Перехідні процеси в досліджуваній системі цілком задовільні щодо стійкості, швидкодії, рівня і періоду коливань. Також розроблена модель дозволяє отримати розрахункові, технічні характеристики і параметри створюваного об'єкта при необхідних навантаженнях і передбачуваних умовах експлуатації.

1. Кривиов В.С., Алейников А.М., Яковлев А.И. Неисчерпаемая энергия. Кн.1. Ветроэлектрогенераторы. Учебник. Харьков: Нац. аэрокосм. ун-т «Харьк. авиац. ин-т». Севастополь. Севаст. нац. техн. ун-т. 2003. 400 с.

2. J. Charles Barnhart, Michael Dale, Adam R. Brandtb and Sally M. Bensona. The energetic implications of curtailing 
versus storing solar- and wind-generated electricity. Energy Environ. Sci. 2013. 6. Pp. 2804-2810.

3. Vasko P., Verbovij A., Moroz A., Pazych S. Ibragimova M., Sahno L. Concept of Accumulation of Energy from Photovoltaic and Wind Power Plants by Means of Seawater Pumped Hydroelectric Energy Storage. 2019 IEEE 6th International Conference on Energy Smart Systems (ESS). Kyiv. Ukraine. 2019. Pp. 188-191. doi: 10.1109/ESS.2019.8764167.

4. Васько П.Ф., Ибрагимова М.Р., Пазыч С.Т. Гидроакумулирующие электростанции на морской воде технологическая основа крупномасштабного использования ветровой и солнечной энергии в электроэнергетической системе Крыма. Alternative Energy and Ecology. ISJAEE. № 15(155). 2014. C. 38-49. ISSN 1608-8298.

5. Васько П.Ф., Вербовий А.П., Ібрагімова М.Р., Пазич C.T. Гідрокумулювальні електростанціїтехнологічна основа інтеграції потужних вітро- та фотоелектричних станцій до складу електроенергетичної системи. Гідроенергетика України. 2017. № 1-2. С. 20-25.

6. Харитонов В.П. Автономные ветроэлектрические установки. М. 2006. 280 с.

7. Холодов Д.В., Обухов Е.В., Степанов В.Н., Полнарев С.Я. Нетрадиционные стратегии в освоении природных энергоресурсов приморских регионов Украины. О. Астропринт. 2003. 162 с.

8. Серебряников Н.И., Родионов В.Г., Кулешов А.П., Магрук В.И., Иванущенко В.С. Гидроаккумулирующие электростанции. Строительство и эксплуатация Загорской ГАЭС. М. Издательство НЦ ЭНАС. 2000. 368 с.

ISBN 5-93196-024-4.

9. Синюгин В.Ю., Магрук В.И., Родионов В.Г. Гидроаккумулирующие электростанции в современной электроэнергетике. М. Издательство НЦ ЭНАС. 2008. 352 c. ISBN 978-593196-917-6.

10. Schnitzer $V$. Pumpenantriebe mit regenerativer Energie; ihre besondere Anforderungen an Pumpen. Pumpentagung Karlsruhe'92, Fachgemeinschaft Pumpen im VDMA. Frankfurt/Main. Oktober 1992. Beitrag A5-11.

11. Pumps as turbines for hydraulic energy recovery and small hydropower purposes in Poland. 2008. [Електронний pecypc]. URL: https://www.researchgate.net/publication/269992 $\underline{946}$ (дата звернення: 12.09.2019).

12. Nourbakhsh A. Mini and Micro Hydropower Stations for Production Inexpensive Energy. HIDROENERGIA 2008-0504. Intern. Conf. and Exhibition, SMALL HYDROPOWER. Bled-Slovenia. 11-13 June 2008.

13. Черных И. В. SIMULINK: среда создания инженерных приложений. М. ДИАЛОГ МИФИ. 2004. 496 с.

14. Gagnon R., Saulnier B., Sybille G., Giroux P. Modeling of a Generic High-Penetration No-Storage WindDiesel System Using Matlab/Power System Blockset. 2002 Global Windpower Conference. April 2002. Paris. France.
15. Вербовий А.П. Структурна схема імітаційної моделі автономної гідроакумулювальної електростанції. Матеріали 20 міжнародної наук.-практ. конференції «Відновлювана енергетика i енергоефективність у 21 столітті». 15-16 травня 2019 р. Київ. С. 506-510.

16. Лежнюк П.Д., Никиторович Р.В., Жан-Пьер Нгома. Компенсация реактивной мощности асинхронных генераторов на малых гидроэлектростанциях. Энергетика и электротехника. Наукові праці. ВНТУ. 2008. № 2. C. 1-7.

17. Singh P., Ramasubramanian V., Rao A. Performance Evaluation of the Pump as Turbine based Micro Hydro Project in Kinko Village. Tanzania. Himalayan Small Hydropower Summit, Dehradun. India. October 12-13. 2006. Pp. 159-166.

18. Maher P., Smith N. A., Williams A. A. Assessment of pico hydro as an option for off-gridelectrification in Kenya. Renewable Energy. 2003. Vol. 28. Pp. 1357-1369.

19. Васько П.Ф., Вербовий А.П., Пазич С.Т. Реалізація стохастичної моделі поздовжньої складової швидкості вітру для задач вітроенергетики. Відновлювана енергетика. 2017. № 3. С. 54-61.

20. Вербовий А.П., Пазич С.T. Моделювання динамічних $\mathrm{i}$ квазістатичних режимів роботи вітроводонасосної установки 3 урахуванням стохастичної складової швидкості вітру. Відновлювана енергетика. 2018. № 4(55). С. 25-33.

21. Брыль А.О., Васько В.П., Васько П.Ф., Соловйов П.Б. Математическое моделирование пусковых режимов синхронных и асинхронных генераторов малых ГЭС. Альтернативная энергетика и екологія (ISJAEE). 2014. № 15. C. 71-81.

\section{REFERENCE}

1. Krivcov V.S.,Alejnikov A.M., Yakovlev A.I. Neischerpaemaya energiya. Kn.1. Vetroelektrogeneratory. [Inexhaustible energy. Book 1. Wind power generators]. Uchebnik. Harkov: Nac. aerokosm. un-t «Hark.aviac. in-t». Sevastopol. Sevast. nac. tekhn. un-t. 2003. 400 p. [in Russian].

2. J. Charles Barnhart, Michael Dale, Adam R. Brandtb and Sally M. Bensona. The energetic implications of curtailing versus storing solar- and wind-generated electricity. Energy Environ. Sci. 2013. 6. Pp. 2804-2810. [in English].

3. Vasko P., Verbovij A., Moroz A., Pazych S. Ibragimova M., Sahno L. Concept of Accumulation of Energy from Photovoltaic and Wind Power Plants by Means of Seawater Pumped Hydroelectric Energy Storage. 2019 IEEE 6th International Conference on Energy Smart Systems (ESS). Kyiv. Ukraine. 2019. Pp. 188-191. doi: 10.1109/ESS.2019.8764167. [in English].

4. Vasko P.F., Ibragimova M.R., Pazych S.T. Gidroakumuliruyushchie elektrostancii na morskoj vodetekhnologicheskaya osnova krupnomasshtabnogo ispolzovaniya vetrovoj i solnechnoj energii $\mathrm{v}$ elektroenergeticheskoj sisteme 
Kryma. [Hydroelectric seawater power plants are the technological basis for the large-scale use of wind and solar energy in the Crimean power system]. Alternative Energy and Ecology. ISJAEE. No. 15(155). 2014. Pp. 38-49. ISSN 16088298. [in Russian].

5. Vasko P.F., Verbovyi A.P., Ibrahimova M.R., Pazych S.T. Hidroakumuliuvalni elektrostantsii - tekhnolohichna osnova intehratsii potuzhnykh vitro- ta fotoelektrychnykh stantsii do skladu elektroenerhetychnoi systemy. [Hydroaccumulation power plants are the technological basis for the integration of powerful wind and photovoltaic power plants into the power system]. Hidroenerhetyka Ukrainy. 2017. No. 1-2. Pp. 20-25. [in Ukrainian].

6. Haritonov V.P. Avtonomnye vetroelektricheskie ustanovki. [Autonomous wind power plants]. M. 2006. 280 p. [in Russian].

7. Holodov D.V., Obuhov E.V., Stepanov V.N., Polnarev S.Ya. Netradicionnye strategii v osvoenii prirodnyh energoresursov primorskih regionov Ukrainy. [Non-traditional strategies in the development of natural energy resources of the coastal regions of Ukraine]. O. Astroprint. 2003. 162 p. [in Russian].

8. Serebryanikov N.I., Rodionov V.G., Kuleshov A.P., Magruk V.I., Ivanushchenko V.S. Gidroakkumuliruyushchie elektrostancii. [Pumped storage power plants. Construction and operation of the Zagorskaya PSPP]. Stroitelstvo i ekspluataciya Zagorskoj GAES. M. Izdatelstvo NC ENAS. 2000. 368 p. ISBN 5-93196-024-4. [in Russian].

9. Sinyugin V.Yu., Magruk V.I., Rodionov V.G. Gidroakkumuliruyushchie elektrostancii v sovremennoj elektroenergetike. [Pumped storage power plants in the modern electric power industry]. M. Izdatelstvo NC ENAS. 2008. 352 p. ISBN 978-593196-917-6. [in Russian].

10. Schnitzer $V$. Pumpenantriebe mit regenerativer Energie; ihre besondere Anforderungen an Pumpen. Pumpentagung Karlsruhe92, Fachgemeinschaft Pumpen im VDMA. Frankfurt/Main. Oktober 1992. Beitrag A5-11. [in English].

11. Pumps as turbines for hydraulic energy recovery and small hydropower purposes in Poland. 2008. [Electronic resource]. URL: https://www.researchgate.net/publication/26999 2946 (Applying date: 12.09.2019). [in English].

12. Nourbakhsh A. Mini and Micro Hydropower Stations for Production Inexpensive Energy. HIDROENERGIA 2008-0504. Intern. Conf. and Exhibition, SMALL HYDROPOWER. Bled-Slovenia. 11-13 June 2008. [in English].

13. Chernyh I. V. SIMULINK: sreda sozdaniya inzhenernyh prilozhenij. [SIMULINK: an environment for creating engineering applications]. M. DIALOG MIFI. 2004. 496 p. [in Russian].

14. Gagnon R., Saulnier B., Sybille G., Giroux P. Modeling of a Generic High-Penetration No-Storage WindDiesel System Using Matlab/Power System Blockset. 2002 Global Windpower Conference. April 2002. Paris. France. [in English].

15. Verbovyi A.P. Strukturna skhema imitatsiinoi modeli avtonomnoi hidroakumuliuvalnoi elektrostantsii. [Block diagram of a simulation model of an autonomous storage power plant]. Materialy 20 mizhnarodnoi nauk.-prakt. konferentsii «Vidnovliuvana enerhetyka i enerhoefektyvnist u 21 stolitti». 1516 travnia 2019 r. Kyiv. Pp. 506-510. [in Ukrainian].

16. Lezhnyuk P.D., Nikitorovich R.V., Zhan-P'er Ngoma. Kompensaciya reaktivnoj moshchnosti asinhronnyh generatorov na malyh gidroelektrostanciyah. [Compensation of reactive power of asynchronous generators at small hydroelectric power plants]. Energetika i elektrotekhnika. Naukovi praci. VNTU. 2008. No. 2. Pp. 1-7. [in Russian].

17. Singh P. Performance Evaluation of the Pump as Turbine based Micro Hydro Project in Kinko Village, Tanzania. P. Singh, V. Ramasubramanian, A. Rao. Himalayan Small Hydropower Summit, Dehradun. India. October 12-13. 2006. Pp. 159-166. [in English].

18. Maher P., Smith N. A., Williams A. A. Assessment of pico hydro as an option for off-gridelectrification in Kenya. Renewable Energy. 2003. Vol. 28. Pp. 1357-1369. [in English].

19. Vasko P.F., Verbovyi A.P., Pazych S.T. Realizatsiia stokhastychnoi modeli pozdovzhnoi skladovoi shvydkosti vitru dlia zadach vitroenerhetyky. [Implementation of a stochastic model of the longitudinal component of wind speed for wind energy problems]. Vidnovluvana energetika. 2017. No. 3. Pp. 54 61. [in Ukrainian].

20. Verbovyi A.P., Pazych S.T. Modeliuvannia dynamichnykh i kvazistatychnykh rezhymiv roboty vitrovodonasosnoi ustanovky $\mathrm{z}$ urakhuvanniam stokhastychnoi skladovoi shvydkosti vitru. [Modeling of dynamic and quasistatic modes of operation of a wind pump installation taking into account the stochastic component of wind speed]. Vidnovluvana energetika. 2018. No. 4(55). Pp. 25-33. [in Ukrainian].

21. Bryl A.O., Vasko V.P., Vasko P.F., Solovjov P.B. Matematicheskoe modelirovanie puskovyh rezhimov sinhronnyh i asinhronnyh generatorov malyh GES. [Mathematical modeling of starting modes of synchronous and asynchronous generators of small hydroelectric power plants]. Alternativnaya energetika i ekologiya (ISJAEE). 2014. No. 15. Pp. 71-81. [in Russian].

Стаття надійшла до редакції 16.11.21 Остаточна версія 03.12.21 